\title{
LOYALITAS KONSUMEN KFC HASANUDDIN DI KOTA PALU (Studi Pada Konsumen KFC Hasanuddin)
}

\author{
ARYANTO ALFREDO \\ CHALIL \\ NIRWAN \\ Program Studi Manajemen, Fakultas Ekonomi, Universitas Tadulako \\ Email: aryawiguna935@gmail.com
}

\begin{abstract}
This study aims to know the factors of Consumer Loyalty KFC Hasanuddin in Palu City. Independent variables used in this study are Value (price and quality) (XI), Image (reputation of the brand) (X2), Convenience and ease to get goods or services (X3), Satisfaction perceived by consumer (X4) (X5), Warranty and Guarantee (X6) While the dependent variable is Consumer Loyalty (Y).This research type is quantitative.The method of this research is descriptive causal.The samples used in this research are as many as 105 respondents with the form of sampling using technique purposive sampling The method of data analysis used in this study is multiple linear regression analysis method.The results of this study indicate that Factors Value, Image, Comfort And Convenience, Satisfaction, Service, Warranty And Guarantee Affecting Consumer Loyalty (Study At KFC Hasanuddin In Palu City) simultaneously have a significant effect on consumer loyalty to KFC Hasanuddin in Pa City lu. Partially Factor-Factor Value, Image, Convenience And Convenience, Satisfaction, Service, Warranty And Guarantee Affect Consumer loyalty significantly influence consumer loyalty to KFC Hasanuddin in Palu City.
\end{abstract}

Keywords: Value, Image, Service, Warranty, Guarantee.

\begin{abstract}
ABSTRAK
Penelitian ini bertujuan untuk mengetahui faktor-faktor loyalitas Konsumen KFC Hasanuddin di Kota Palu. Variabel independen yang digunakan dalam penelitian ini adalah Nilai (harga dan kualitas) (X1), Citra (reputasi dari merek tersebut) (X2), Kenyamanan dan kemudahan untuk mendapatkan barang atau jasa (X3), Kepuasan yang dirasakan oleh konsumen (X4), Pelayanan (X5), Garansi dan jaminan (X6. Sedangkan variabel dependen adalah Loyalitas konsumen (Y). Jenis penelitian ini adalah kuantitatif. Metode penelitian ini adalah deskriptif kausal. Sampel yang digunakan pada penelitian ini yaitu sebanyak 105 responden dengan bentuk pengambilan sampel menggunakan teknik purposive sampling. Metode analisis data yang digunakan dalam penelitian ini adalah metode analisis regresi linear berganda. Hasil penelitian ini menunjukkan bahwa Faktor-Faktor Nilai, Citra, Kenyamanan dan Kemudahan, Kepuasan, Pelayanan, Garansi dan Jaminan yang memengaruhi Loyalitas Konsumen (Studi Pada KFC Hasanuddin Di Kota Palu) secara serempak berpengaruh signifikan terhadap loyalitas konsumen pada KFC Hasanuddin di Kota Palu. Secara parsial FaktorFaktor Nilai, Citra, Kenyamanan dan Kemudahan, Kepuasan, Pelayanan, Garansi dan Jaminan yang Memengaruhi loyalitas Konsumen berpengaruh signifikan terhadap loyalitas konsumen pada KFC Hasanuddin di Kota Palu.
\end{abstract}

Kata kunci: Nilai, Citra, Pelyanan, Garansi, Jaminan.

\section{PENDAHULUAN}

Masyarakat Kota Palu sangat menikmati untuk makan di luar rumah demi menjaga arti pentingnya waktu. Salah satu jenis waralaba yang berkembang pesat saat ini adalah restoran cepat saji, restoran cepat saji merupakan hal yang trend di sambut oleh semua kalangan, karena restoran cepat saji menjanjikan kepraktisan dan yang pasti cepat saji. Hal ini telah membuat tumbuh pesatnya tempat makan siap saji (fast food) di kota palu. Berbagai makanan cepat saji asing mulai masuk ke kota Palu, seperti Kentucky Fried Chiken, Maestro pizza, Pizza Hut, Quick Chiken. Makanan siap saji adalah makanan yang diolah dan disajikan dengan waktu yang cepat (dimana pelanggan masih merasa senang untuk menunggu), dengan menggunakan standar tertentu, baik dalam produk, mutu, dan 
Alfredo, A.

pelayanan. Salah satu makanan yang digemari oleh masyarakat di kota Palu adalah ayam. Hal ini merupakan peluang pasar yang sangat menjanjikan, sehingga Kentucky Fried Chiken membuka cabang di Kota Palu tepatnya di jalan Hasanuddin no 15, KFC sendiri masuk di Kota Palu tepatnya pada 10 Desember 1996. Menurut Doyo (2006:45) menyebutkan enam faktor utama yang memengaruhi loyalitas konsumen, sebagai berikut:

1. Nilai (harga dan kualitas)

2. Citra (reputasi dari merek tersebut)

3. Kenyamanan dan kemudahan untuk mendapatkan barang atau jasa

4. Kepuasan yang dirasakan oleh konsumen

5. Pelayanan

6. Garansi dan jaminan

Nilai (harga dan kualitas) menurut Alma (2014:169) harga adalah nilai suatu barang yang dinyatakan dengan uang, sedangkan menurut Abdullah dan Tantri (2012) kualitas adalah keseluruhan ciri dan karakteristik suatu barang atau jasa yang berpengaruh pada kemampuannya untuk memuaskan kebutuhan yang dinyatakan maupun yang tersirat. Nilai (harga dan kualitas) kaitanya dengan KFC Hasanuddin di Kota Palu yaitu KFC Hasanuddin selalu memperhatikan kualitas makanan yang disediakan baik dari makanan yang enak dan tempat yang bersih, tampilan makanan yang mengundang selera, dan produk makanan yang lezat dan KFC sendiri pun memberikan Harga makanan yang sesuai dengan ekonomi menengah ke bawah.

Citra (reputasi dari merek tersebut) menurut Sangadji dan Shopiah (2013) citra merek adalah seperangkat asosiasi unik yang ingin diciptakan atau dipelihara oleh pemasar. Asosiasi-asosiasi itu menyatakan apa sesungguhnya merek dan apa yang dijanjikan kepada konsumen. Citra (reputasi dari merek tersebut) kaitanya dengan KFC Hasanuddin di Kota Palu yaitu KFC sendiri sudah memiliki reputasi yang baik di pandang masyarakat Kota Palu, itu didapatkan dengan cara memberikan konsumen pelayanan yang ramah,baik, dan cepat agar konsumen tidak komplen ke KFC Hasanuddin di Kota Palu.

Kenyamanan dan kemudahan untuk mendapatkan barang atau jasa menurut Irawan (2009:39) kenyamanan dan kemudahan adalah apabila relatif mudah, nyaman dan efisien dalam mendapatkan produk atau pelayanan. Kenyamanan dan kemudahan untuk mendapatkan barang atau jasa kaitanya dengan KFC Hasanuddin di Kota Palu yaitu konsumen bisa lebih mudah dan cepat membayar karena memiliki kasir yang banyak, konsumen juga sekarang bisa memesan makanan lebih mudah dan cepat dengan cara menelfon KFC Hasanuddin di nomor (0451) 425126 dan makanan tersebut akan di antarkan ke rumah anda. Inilah salah satu strategi KFC Hasanuddin di Kota Palu untuk bisa membuat konsumen lebih mudah dan nyaman terhadap KFC.

Kepuasan yang dirasakan oleh konsumen, menurut Kotler (2011:70) kepuasan pelanggan adalah perasaan senang atau kecewa seseorang yang muncul setelah membandingkan antara kinerja (hasil) produk yang dipikirkan terhadap kinerja (atau hasil) yang diharapkan. Kepuasan yang dirasakan oleh konsumen kaitanya dengan KFC Hasanuddin di Kota Palu bisa terjadi apabila konsumen sudah mendapatkan apa yang mereka mau seperti makanan yang lezat dan pelayanan yang baik dan cepat di KFC Hasanuddin di Kota Palu, karena semakin konsumen merasakan kepuasan yang besar, semakin besar pula konsumen tersebut menjadi Loyal pada KFC Hasanuddin di Kota Palu.

Pelayanan, menurut Fandy Tjiptono (2014:268) definisi kualitas pelayanan berfokus pada upaya pemenuhan kebutuhan dan keinginan konsumen serta ketepatan penyampaianya untuk mengimbangi harapan konsumen. Pelayanan kaitanya dengan KFC Hasanuddin di Kota Palu yaitu KFC Hasanuddin di Kota Palu memberikan pelayanan terbaik buat konsumenya baik itu dari karyawan yang profesional atau dari desain tempat yang nyaman buat konsumenya, agar konsumennya bisa merasakan kenyamanan saat makan di KFC Hasanuddin di Kota Palu. 
Garansi dan Jaminan, menurut Tjiptono $(2008 ; 104)$ Jaminan adalah janji yang merupakan kewajiban produsen atau produknya kepada konsumen, diman para konsumen akan diberi ganti rugi bila produk ternyata tidak bisa berfungsi sebagiman yang diharapkan dan dijanjikan. Garansi dan jaminan kaitanya dengan KFC Hasanuddin di Kota Palu yaitu KFC sendiri memberikan pelayanan karyawan yang memiliki dan keterampilan yang profesional, agar konsumen KFC Hasanuddin di Kota Palu bisa merasa terjamin dengan apa yang diberikan KFC itu sendiri.

\section{KAJIAN LITERATURE}

\section{Pengertian Pemasaran Jasa}

Pemasaran dan jasa merupakan suatu proses yang dapat mempersepsikan, memahami, menstimulasi, dan memenuhi kebutuhan pasar sasaran yang dipilih secara khusus dengan menyalurkan sumber-sumber sebuah organisasi atau perusahaan untuk memenuhi kebutuhan tersebut (Payne 2000:1).

\section{Pengertian Loyalitas Konsumen}

Menurut Kotler dan Keller (2012) loyalitas konsumen adalah komitmen yang di pegang secara mendalam untuk membeli atau mendukung kembali produk atau jasa yang di sukai di masa depan meski pengaruh situasi dan usaha pemasaran berpotensi menyebabkan pelanggan beralih ke perusahaan lainya.

\section{Karakteristik Loyalitas}

Loyalitas Konsumen merupakan ukuran yang dapat di andalkan untuk memprediksi pertumbuhan penjualan dan juga loyalitas pelanggan dapat didefinisikan berdasarkan perilaku pembelian yang konsisten (Griffin,2009:31). Berikut adalah karakteristik dari Loyalitas Konsumen :

1. Melakukan pembelian berulang secara teratur. Konsumen melakukan pembelian secara continue pada suatu produk tertentu. Contoh: pecinta motor Harley Davidson akan membeli motor Harley baru jika ada model Harley Davidson yang terbaru, bahkan tidak hanya membeli tetapi mereka juga mengeluarkan uang tambahan untuk mengubahnya sesuai dengan keinginan mereka.

2. Membeli antar lini produk atau jasa (purchase across product and service lines). Konsumen tidak hanya membeli jasa dan produk utama tetapi konsumen juga membeli lini produk dan jasa dari perusahaan yang sama. Contoh: konsumen tidak hanya membeli motor Harley Davidson saja, tetapi mereka juga membeli aksesoris dari Harley Davidson untuk mempercantik motor mereka.

3. Mereferensikan kepada orang lain (Refers other). Dimana konsumen melakukan komunikasi dari mulut ke mulut (word of mouth) berkenaan dengan produk tersebut. Contoh: seorang konsumen Harley Davidson yang sudah lama mamakai motor tersebut, menceritakan tentang kehebatan dan keunggulan dari motor tersebut, kemudian setelah itu temanya tertarik untuk membeli motor Harley Davidson karena mendengar cerita tersebut.

4. Menunjukan kekebalan terhadap tarikan dari pesaing (demonstrates an immunity to the full of the competition). Konsumen menolak untuk menggunakan produk atau jasa alternative yang ditawarkan oleh pesaing. Contoh: para pecinta motor Harley Davidson menolak untuk menggunakan motor lain, bahkan mereka juga cenderung menolak untuk mengetahui ada jenis jenis motor lainya.

\section{Faktor-Faktor Yang Memengaruhi Loyalitas}

Menurut Doyo (2006:45) menyebutkan enam faktor utama yang memengaruhi Loyalitas Konsumen, sebagai berikut:

1. Nilai (harga dan kualitas). Penggunaan suatu produk dalam jangka waktu yang lama akan mengarahkan pada loyalitas, karena itu pihak perusahaan harus bertanggung jawab untuk menjaga 
Alfredo, A.

merek tersebut. Perlu diperhatikan, pengurangan standar kualitas dari suatu merek akan mengecewakan konsumen bahkan konsumen yang paling loyal sekalipun begitu juga dengan perubahan harga, karena itu pihak perusahaan harus mengontrol kualitas merek beserta harganya.

2. Citra (reputasi dari merek tersebut). Citra dari perusahaan dan merek diawali dengan kesadaran. Produk yang memiliki citra yang baik akan dapat menimbulkan loyalitas konsumen pada merek.

3. Kenyamanan dan Kemudahan untuk Mendapatkan Barang atau Jasa. Situasi yang penuh tekanan dan permintaan terhadap pasar yang menuntut akan adanya kemudahan, pihak perusahaan dituntut untuk menyediakan produk atau jasa yang nyaman dan mudah untuk didapatkan.

4. Kepuasan yang Dirasakan Oleh Konsumen. Kepuasan yang dirasakan oleh konsumen sangat berpengaruh terhadap sifat Loyalitas pelanggan dimasa yang akan datang, semakin konsumen merasakan kepuasan yang besar, semakin besar pula konsumen tersebut menjadi loyal kepada suatu merek.

5. Pelayanan. Kualitas pelayanan yang baik yang diberikan oleh perusahaan sangat dapat memengaruhi loyalitas konsumen pada perusahaan.

6. Garansi dan Jaminan. Garansi yang diberikan perusahaan apabila tidak bisa menyediakan pelayanan yang prima kepada pelanggannya.

\section{Tahapan Loyalitas}

Menurut Stöcklin dan Opwis (2008) mengurutkan tahapan loyalitas menjadi empat tahap:

a. Yang pertama, loyalitas kognitif, menjadi dasar atas kepercayaan terhadap citra merek; tersedianya atribut informasi bagi para pelanggan yang menunjukan merek itu adalah lebih baik dari pada alternatif merek lainnya.

b. Tahap kedua loyalitas afektif, kecenderungan dari suatu kegemaran atau sikap terhadap merek diperlukan, berbasis pada beberapa pengalaman yang memuaskan.

c. Tahap berikutnya, kesetiaan conative, menyiratkan satu kesanggupan untuk keinginan membeli kembali dan oleh karena itu, menyertakan pelanggan lebih kepada perusahaan dibandingkan loyalitas afektif. Bagaimanapun, hasrat untuk melakukan pembelian ulang mungkin saja dapat diantisipasi, sekalipun demikian lengkah-langkahnya belum tentu dapat direalisasikan.

d. Tahap keempat adalah tindakan loyalitas: niat mendorong transformasi ke dalam kesiapan untuk bertindak, disertai oleh suatu keinginan untuk mengatasi rintangan yang mungkin mencegah tindakan.

\section{Jenis-Jenis Loyalitas}

Setelah mengetahui siklus pembelian pelanggan, pada langkah terakhir yaitu pembelian kembali biasanya rasa loyalitas sudah tumbuh pada diri pelanggan. Namun untuk berbagai alasan, beberapa pelanggan tidak mengembangkan loyalitasnya terhadap suatu produk yang digunakan. Menurut Griffin (2005:22) loyalitas pelanggan dapat dibagi menjadi 4, yaitu:

1. Tanpa Loyalitas

Pembeli yang telah membeli produk tidak memperdulikan dimana mereka membeli asal mereka mendapatkan apa yang mereka butuhkan. Mereka tidak memilihi ikatan emosional terhadap produk atau jasa yang mereka gunakan.

2. Loyalitas yang Lemah (Inertia Loyalty)

Pelanggan yang membeli produk karena kebiasaan. Biasanya jenis pembelian ini dilakukan karena mereka selalu menggunakan produk tersebut dan mereka merasakan tingkat kepuasan tertentu dengan perusahaan. Loyalitas ini umumnya terjadi pada produk yang sering dibeli.

3. Loyalitas Tersembunyi (Latent Loyalty)

Biasanya loyalitas ini terjadi karena faktor situasi dan bukan pengaruh sikap yang menentukan pembelian berulang dimana pelanggan tidak dapat melakukan pembelian karena adanya situasi tertentu yang menahan pembelian berulang tersebut. 


\section{Loyalitas Premium}

Loyalitas Premium merupakan jenis loyalitas yang terjadi apabila suatu tingkat ketertarikan yang tinggi berjalan dengan selaras dengan aktifitas pembelian kembali. Loyalitas seperti inilah yang sangat diharapakan oleh perusahaan pada tingkat prefensi yang tinggi, maka konsumen akan bangga menemukan dan menggunakan produk tersebut dan dengan senang hati membagi pengetahuan dari pengalaman mereka kepada teman, keluarga, atau konsumen lainya.

\section{Strategi Membangun Loyalitas}

Menurut Griffin (2005:209) Strategi membangun Loyalitas menurut tahapan tahapan konsumen dibagi menjadi:

1. Tersangka dan prospek.

Tersangka adalah orang yang mungkin membeli jasa atau produk. Disebut tersangka karena penjual percaya atau menyangka mereka akan membeli tetapi penjual belum cukup yakin. Prospek adalah orang yang membutuhkan produk atau jasa dan memiliki kemampuan untuk membeli.

Penyedia produk harus bisa mengatasi rasa takut seperti suspectprospect dengan langkah tindakan sebagai berikut:

a. Memproyeksikan citra kepemimpinan.

b. Dengarlah atau mencari ketakutan pembeli,

c. Mengatasi rasa takut pembeli dengan empati atau dorongan. Kisah keberhasilan klien, tawaran konsultasi gratis dan garansi produk atau jasa.

2. Konsumen pertama kali.

Konsumen pertama kali adalah orang yang telah membeli satu kali . Orang tersebut bisa jadi merupakan konsumen sendiri dan sekaligus konsumen pesaing untuk itulah focus utama dalam konsumen pertama kali dengan memenuhi atau melampaui harapan konsumen, dengan langkahlangkah tindakan yaitu:

a. Melampaui harapan konsumen baru.

b. Membangun fisi untuk kunjungan ulang.

c. Mengucapkan terima kasih atas bisnis dari konsumen.

d. Mengundang konsumen untuk membeli.

3. Konsumen berulang.

Konsumen berulang adalah orang yang telah membeli dua kali atau lebih. Mereka mungkin telah membeli produk yang sama dua kali atau membeli produk dan jasa yang berbeda pada dua kesempatan atau lebih. Fokus utama pada konsumen ini yaitu dengan memberikan manfaat bernilai tambah atas masing-masing pembelian ulang, dengan langkah-langkah tindakan yaitu:

a. Menemukan atau memenuhi kebutuhan konsumen dengan menggunakan kunjungan bernilai tambah perangkat cross selling.

b. Menjual produk dan jasa pembentuk loyalitas.

c. Menganalisa pembelian kepada pesaing atau peralian tetap atau perpindahan sementara.

d. Mintalah umpan balik dari konsumen secara teratur.

4. Klien.

Klien adalah konsumen yang membeli apapun yang di jual dan dan yang ia dapat pergunakan serta membelinya secara teratur, memiliki hubungan yang kuat dan berlanjut yang menjadikan kebal terhadap tarikan pesaing. Fokus utama untuk konsumen ini yaitu menyesuaikan jasa dengan hubungan klien tertentu, dengan langkah-langkah tindakan yaitu:

a. Mempraktekkan pelayanan yang disesuaikan dengan kebutuhan. Mencari cara untuk membantu konsumen menemukan kembali diri mereka sendiri.

b. Jangan menganggap bisnis dari konsumen akan terjadi dengan sendirinya.

c. Membuat klien mengetahui bahwa berbisnis dengan anda merupakan hal yang cerdas. 
d. Mencari input dan umpan balik secara kontinyu.

5. Penganjur

Penganjur yaitu pendukung yang membeli produk serta membelinya secara teratur, tetapi penganjur juga mendorong orang lain untuk membeli, ia membicarakan produsen, melakukan pemasaran dan membawakan konsumen ke pada produsen. Fokus utama yaitu membuat banyak klien untuk melakukan penjualan untuk produsen.

\section{Kerangka Pemikiran}
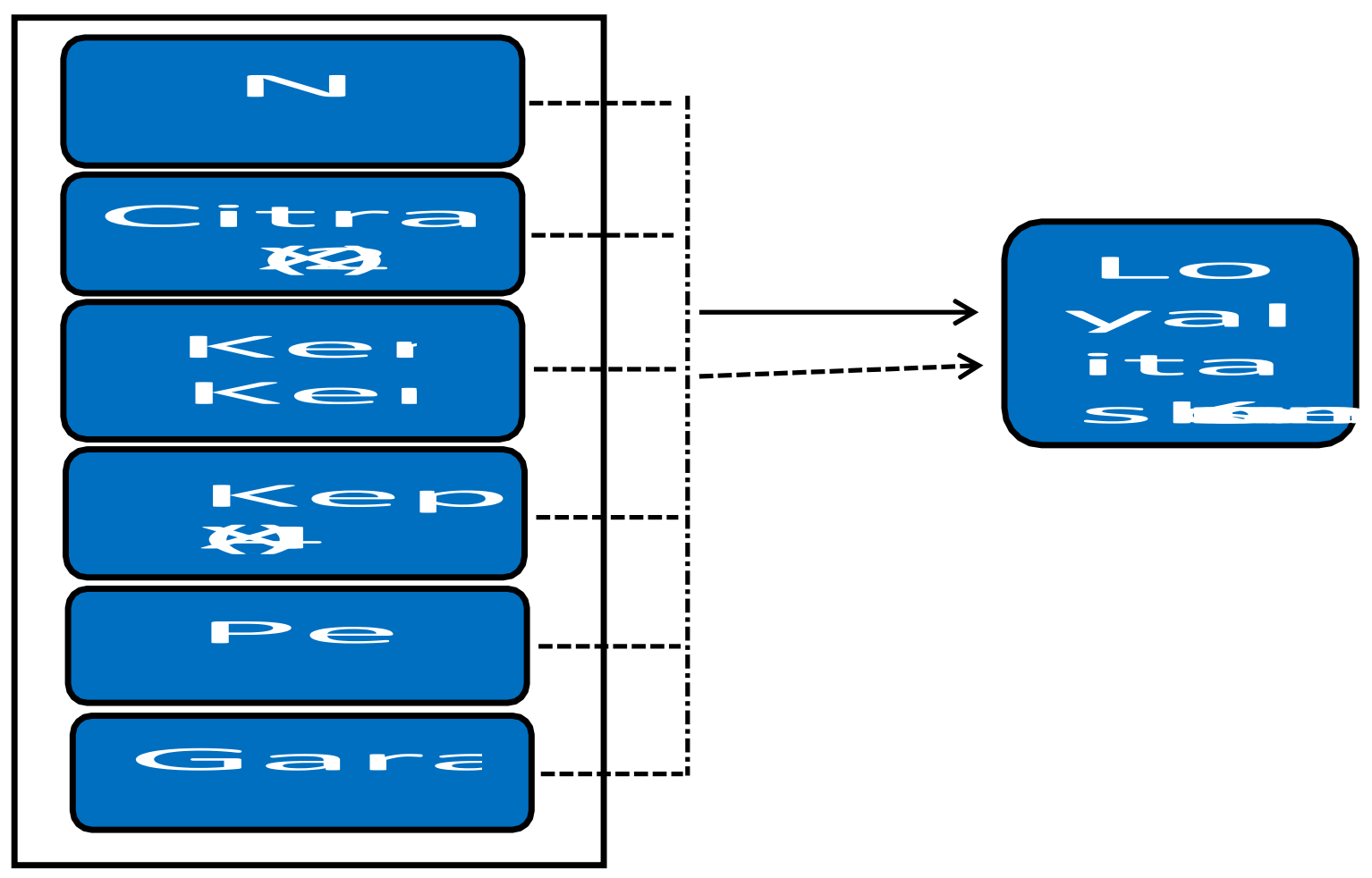

Gambar 1

Kerangka Pemikiran

Teori dari kerangka berpikir di atas dapat disusun beberapa hipotesis sebagai berikut:

1. Variabel Nilai (harga dan kualitas), Citra (reputasi dari merek tersebut), Kenyamanan dan Kemudahan untuk Mendapatkan Barang atau Jasa, Kepuasan yang dirasakan oleh konsumen, Pelayanan, Garansi dan Jaminan secara serempak berpengaruh signifikan terhadap Loyalitas Konsumen KFC Hasanuddin di Kota Palu.

2. Variabel Nilai (harga dan kualitas) berpengaruh signifikan terhadap Loyalitas Konsumen KFC Hasanuddin di Kota Palu.

3. Variabel Citra (reputasi dari merek tersebut) berpengaruh signifikan terhadap Loyalitas Konsumen KFC Hasanuddin di Kota Palu.

4. Variabel Kenyamanan dan Kemudahan untuk Mendapatkan Barang atau Jasa, berpengaruh signifikan terhadap Loyalitas Konsumen KFC Hasanuddin di Kota Palu.

5. Variabel Kepuasan yang dirasakan oleh konsumen berpengaruh signifikan terhadap Loyalitas Konsumen KFC Hasanuddin di Kota Palu.

6. Variabel Pelayanan berpengaruh signifikan terhadap Loyalitas Konsumen KFC Hasanuddin di Kota Palu.

7. Variabel Garansi dan Jaminan berpengaruh signifikan terhadap Loyalitas Konsumen KFC Hasanuddin di Kota Palu. 


\section{METODE PENELITIAN}

Penelitian-penelitian ini menggunakan tipe penelitian deskriptif kausal, menurut Kuncoro (2009:12) bahwa penelitian deskriftif meliputi pengumpulan data untuk diuji hipotesis atau menjawab pertanyaan mengenai status terakhir dari subjek penelitian, sedangkan penelitian kausal adalah penelitian yang menunjukkan arah hubungan antara variabel bebas dengan variabel terikat, disamping mengukur kekuatan hubungannya. Teknik pengumpulan data yang dilakukan dengan cara observasi, kuesioner dan dokumentasi. Populasi dalam penelitian ini adalah konsumen yang makan di KFC Hasanuddin di Kota Palu Teknik pengambilan sampel untuk menentukan sampel yang akan digunakan dalam penelitian ini menggunakan purposive sampling. Mengingat jumlah populasi tidak diketahui secara pasti, ukuran sampel dalam penelitian dilakukan dengan menggunakan pendekatan yang dirujuk dari Sugiyono (2013) yang menyatakan bahwa untuk menentukan sampel dari populasi yang tidak diktahui adalah minimal 10 kali dari jumlah variabel yang diteliti (variabel independen dan dependen). Variabel dalam penelitian ini adalah 3 yang terdiri dari variabel indepen dan dependen. Berdasarkan pertimbangan tersebut maka jumlah sampel sebesar $15(6+1)$ variabel yaitu 105 responden dengan demikian sampel dari penelitian ini sebanyak 105 responden.

\section{Alat Analisis}

Metode analisis yang digunakan dalam penelitian ini adalah dengan pendekatan statistik deskriptif melalui penggunaan alat analisis statistik regresi linear berganda untuk mengetahui kekuatan pengaruh variabel $\mathrm{X}$ terhadap variabel $\mathrm{Y}$, dalam hal ini menggunakan bantuan komputer program SPSS Release 20.0.

\section{HASIL DAN PEMBAHASAN}

Tabel 1 Hasil Uji Analisis Regresi Linear Berganda

\begin{tabular}{|c|c|c|c|c|}
\hline \multicolumn{5}{|c|}{ Dependen Variabel Y = Loyalitas Konsumen } \\
\hline \multirow{2}{*}{ Variabel Independen } & \multicolumn{2}{|c|}{ Unstandardized Coefficients } & \multirow{2}{*}{$\frac{\text { Standardized Coefficients }}{\text { Beta }}$} & \multirow{2}{*}{ Sig.t } \\
\hline & B & Std. Error & & \\
\hline (Constant) & 2,879 & 4,073 & & 0,481 \\
\hline (Nilai) $\mathrm{X} 1$ & 0,493 & 0,160 & 0,261 & 0,003 \\
\hline (Citra) X2 & $-0,230$ & 0,093 & $-0,208$ & 0,015 \\
\hline $\begin{array}{l}\text { (Kenyamanan dan Kemudahan untuk } \\
\text { mendapatkan barang atau jasa) X3 }\end{array}$ & 0,289 & 0,088 & 0,296 & 0,001 \\
\hline $\begin{array}{c}\text { (Kepuasan yang dirasakan oleh konsumen) } \\
\text { X4 }\end{array}$ & 0,327 & 0,100 & 0,282 & 0,002 \\
\hline (Pelayanan) X5 & $-0,340$ & 0,126 & $-0,252$ & 0,008 \\
\hline (Garansi dan jaminan) X6 & 0,375 & 0,123 & 0,268 & 0,003 \\
\hline $\begin{array}{ll}\mathrm{R} & =0.610 \\
\mathrm{R} \text { Square } & =0,372\end{array}$ & $\begin{array}{l}\text { Sig. F } \\
\text { Adjusted R }\end{array}$ & $\begin{aligned} & =0,000 \\
\text { are } & =0,333\end{aligned}$ & & \\
\hline
\end{tabular}

Sumber: Data Diolah Oleh Penulis

Berdasarkan penjabaran di atas menunjukkan bahwa, variabel independen yang dianalisis yaitu variabel $\left(\mathrm{X}_{1}, \mathrm{X}_{2}, \mathrm{X}_{3}, \mathrm{X}_{4}, \mathrm{X}_{5}, \mathrm{X}_{6}\right)$ memberikan pengaruh positif terhadap variabel dependen (Y), yaitu Faktor-faktor nilai, citra, kenyamanan dan kemudahan, kepuasan, pelayanan, garansi dan jaminan yang memengaruhi loyalitas konsumen (Studi Pada KFC Hasanuddin di Kota Palu). Untuk lebih jelasnya penjelasan bentuk persamaan tersebut dapat dilihat berikut ini:

1. Nilai konstanta sebesar 2,879 berarti Loyalitas konsumen di KFC hasanuddin Kota palu sebelum adanya variabel independen adalah sebesar 2,879 . 
Alfredo, A.

2. Nilai (Harga dan kualitas) $X_{1}$ dengan nilai koefisien regresi 0,493 ini berarti terjadi pengaruh positif antara Nilai (Harga dan kualitas) dan Loyalitas konsumen. Artinya adalah semakin tinggi Nilai (Harga dan kualitas) yang ada pada KFC Hasanuddin di Kota Palu maka akan menaikkan Loyalitas konsumen.

3. Citra (Reputasi dari merek tersebut) $\mathrm{X}_{2}$ dengan nilai koefisien regresi $-0,203$, nilai citra menjadi rendah bukan karena citra perusahaan KFC Hasanuddin di Kota Palu diturunkan, citra KFC sudah sesuai dengan standar yang diberikan perusahaan pusat, citra KFC dimata konsumen sudah dikenal oleh banyak orang dan di anggap sangat baik akan tetapi konsumen yang sudah sering datang ke KFC Hasanuddin di Kota Palu sudah menganggap citra KFC itu biasa karena keseringannya konsumen melihat dan merasakan citra KFC tersebut. Konsumen ini sudah tergolong konsumen yang memiliki loyalitas premium, dimana loyalitas premium seperti inilah yang sangat diharapkan oleh perusahaan pada tingkat prefensi yang tinggi, maka konsumen KFC Hasanuddin di Kota Palu akan bangga menggunakan produk tersebut dan dengan senang hati membagi pengetahuan dari pengalaman mereka kepada teman, keluarga, atau konsumen lainya, Artinya adalah semakin sesuai Citra (Reputasi dari merek tersebut) yang ada pada KFC Hasanuddin di Kota Palu maka akan menaikkan Loyalitas konsumen.

4. Kenyamanan dan Kemudahan untuk mendapatkan barang atau jasa $X_{3}$ dengan nilai koefisien regresi 0,289 ini berarti terjadi pengaruh positif antara Kenyamanan dan Kemudahan untuk mendapatkan barang atau jasa dan loyalitas konsumen. Artinya adalah semakin tinggi Kenyamanan dan Kemudahan untuk mendapatkan barang atau jasa yang ada pada KFC Hasanuddin di Kota Palu maka akan menaikkan Loyalitas konsumen.

5. Kepuasan yang dirasakan oleh konsumen $X_{4}$ dengan nilai koefisien regresi 0,327 ini berarti terjadi pengaruh positif antara Kepuasan yang dirasakan oleh konsumen dan Loyalitas konsumen. Artinya adalah semakin tinggi Kepuasan yang dirasakan oleh konsumen yang ada pada KFC Hasanuddin di Kota Palu maka akan menaikkan Loyalitas konsumen.

6. Pelayanan $\mathrm{X}_{5}$ dengan nilai koefisien regresi -0,340. Nilai pelayanan menjadi rendah bukan karena pelayanan perusahaan KFC Hasanuddin di Kota Palu diturunkan, pelayanan KFC sudah sesuai dengan standar yang diberikan perusahaan pusat, akan tetapi konsumen yang datang ke KFC Hasanuddin di Kota Palu mengganggap biasa dengan pelayanan yang diberikan karena keseringannya konsumen merasakan pelayanan yang diberikan KFC. Konsumen ini sudah tergolong konsumen yang memiliki loyalitas premium, dimana loyalitas premium seperti inilah yang sangat diharapkan oleh perusahaan pada tingkat prefensi yang tinggi, maka konsumen KFC Hasanuddin di Kota Palu akan bangga menggunakan produk tersebut dan dengan senang hati membagi pengetahuan dari pengalaman mereka kepada teman, keluarga, atau konsumen lainya. Artinya adalah semakin sesuai Pelayanan yang ada pada KFC Hasanuddin di Kota Palu maka akan menaikkan Loyalitas konsumen.

7. Garansi dan jaminan $X_{6}$ dengan nilai koefisien regresi 0,375 ini berarti terjadi pengaruh positif antara Garansi dan jaminan dan Loyalitas konsumen. Artinya adalah semakin tinggi Garansi dan jaminan yang ada pada KFC Hasanuddin di Kota Palu maka akan menaikkan Loyalitas konsumen.

\section{Pengujian Hipotesis}

Tabel 2 Hasil Uji F (Simultan) ANOVA

\begin{tabular}{|rl|r|r|r|r|r|}
\hline Model & & Sum of Squares & df & Mean Square & F & Sig. \\
\hline \multirow{2}{*}{1} & Regression & 295,145 & 6 & 49,191 & 9,659 &, $000^{\mathrm{b}}$ \\
& Residual & 499,102 & 98 & 5,093 & & \\
& Total & 794,248 & 104 & & & \\
\hline
\end{tabular}


Berdasarkan Tabel 2, diperoleh angka signifikan sebesar 0,000. angka 0,000 $<0,05$ oleh karena itu, hipotesis diterima. Hal ini berarti terdapat pengaruh secara simultan pada variabel nilai (harga dan kualitas), citra (reputasi dari merek tersebut), kenyamanan dan kemudahan mendapatkan barang atau jasa, kepuasan yang dirasakan oleh konsumen, pelayanan, garansi dan jaminan terhadap loyalitas konsumen KFC Hasanuddin di Kota Palu.

\section{Pembahasan}

1. Variabel Nilai (harga dan kualitas)

Berdasarkan Tabel 1, hasil pengujian SPSS diperoleh angka signifikan sebesar 0,003. Angka 0,003 $<0,05$ oleh karena itu, hipotesis diterima. Hal ini berarti terdapat pengaruh variabel Nilai (harga dan kualitas) terhadap loyalitas konsumen KFC Hasanuddin di Kota Palu. Pihak perusahaan harus mengontrol kualitas merek beserta harganya karena produk yang mereka jual itu akan memengaruhi loyalitas konsumen pada KFC Hasanuddin di Kota Palu. Kualitas yang baik dapat dilihat dari rasa makanan KFC yang enak dan higenis. Selain itu harga yang lebih murah juga sangat penting, hal ini juga merupakan salah satu strategi perusahaan untuk meningkatkan penjualan pada perusahaan itu sendiri. Hal tersebut tentunya dapat menjadi nilai tambah bagi perusahaan yang akan menarik minat konsumen untuk berbelanja di KFC Hasanuddin di Kota Palu.

Berdasarkan hasil penelitian ini, indikator-indikator yang digunakan untuk mengukur Nilai (harga dan kualitas) berpengaruh signifikan terhadap loyalitas konsumen KFC Hasanuddin di Kota Palu. Hal ini menunjukan bahwa Nilai (harga dan kualitas) merupakan faktor penting yang menunjang loyalitas konsumen. Sehingga dapat di simpulkan bahwa Nilai (harga dan kualitas) yang ditawarkan KFC Hasanuddin di Kota Palu efektif dalam memengaruhi loyalitas konsumen.

2. Variabel Citra (reputasi dari merek tersebut)

Berdasarkan Tabel 1, hasil pengujian SPSS diperoleh angka signifikan sebesar 0,015. Angka 0,015 $<0,05$ oleh karena itu, hipotesis diterima. Hal ini berarti terdapat pengaruh variabel citra (reputasi dari merek tersebut) terhadap loyalitas konsumen KFC Hasanuddin di Kota Palu. Produk yang memiliki citra yang baik akan dapat menimbulkan loyalitas konsumen pada merek. Menurut Kotler dan Keller 2012:263 menyatakan bahwa merek adalah suatu istilah, tanda, simbol, rancangan atau kombinasi dari semuanya, yang dimaksudkan untuk mengindentifikasi barang atau jasa penjual dan untuk menjadi bahan pembeda dari barang atau jasa pesaing. Nilai citra menjadi rendah bukan karena citra perusahaan KFC Hasanuddin di Kota Palu diturunkan, citra KFC sudah sesuai dengan standar yang diberikan perusahaan pusat, citra KFC dimata konsumen sudah dikenal oleh banyak orang dan di anggap sangat baik akan tetapi konsumen yang sudah sering datang ke KFC Hasanuddin di Kota Palu sudah menganggap citra KFC itu biasa karena keseringannya konsumen melihat dan merasakan citra KFC tersebut. Konsumen ini sudah tergolong konsumen yang memiliki loyalitas premium, dimana loyalitas premium seperti inilah yang sangat diharapkan oleh perusahaan pada tingkat prefensi yang tinggi, maka konsumen KFC Hasanuddin di Kota Palu akan bangga menggunakan produk tersebut dan dengan senang hati membagi pengetahuan dari pengalaman mereka kepada teman, keluarga, atau konsumen lainya, dan konsumen tidak akan berpindah ke perusahaan lainya.

3. Variabel Kenyamanan dan kemudahan untuk mendapatkan barang atau jasa

Berdasarkan Tabel 1, hasil pengujian SPSS diperoleh angka signifikan sebesar 0,001. Angka 0,001 $<0,05$ oleh karena itu, hipotesis diterima. Hal ini berarti terdapat pengaruh variabel Kenyamanan dan kemudahan untuk mendapatkan barang atau jasa terhadap loyalitas konsumen KFC Hasanuddin di Kota Palu. Situasi yang penuh tekanan dan permintaan terhadap pasar yang 
Alfredo, A.

menuntut akan adanya kemudahan, pihak KFC dituntut untuk menyediakan produk atau jasa yang nyaman dan mudah untuk didapatkan. Pelanggan akan puas apabila kenyamanan dan kemudahan relatih mudah di dapatkan oleh konsumen, maka akan semakin meningkatkan loyalitas konsumen. Kenyamanan dan kemudahan merupakan variabel yang paling dominan berpengaruh ke loyalitas konsumen KFC Hasanuddin di Kota Palu, adapun indikator-indikator untuk mengukur variabel ini adalah tempat yang nyaman, menyediakan pesan antar kerumah konsumen, kemudahan membayar makanan, memiliki fasilitas yang lengkap seperti AC dan toilet, selalu memperhatikan kebersihan.

4. Variabel Kepuasan yang dirasakan oleh konsumen

Berdasarkan Tabel 1, hasil pengujian SPSS diperoleh angka signifikan sebesar 0,002. Angka 0,002 $<0,05$ oleh karena itu, hipotesis diterima. Hal ini berarti terdapat pengaruh variabel Kepuasan yang dirasakan oleh konsumen terhadap loyalitas konsumen KFC Hasanuddin di Kota Palu. Kepuasan konsumen merupakan suatu hal yang sangat berharga demi mempertahankan keberadaan konsumen tersebut untuk tetap berjalannya suatu bisnis atau usaha. Layanan yang diberikan kepada konsumen akan memacu puas tidaknya seorang konsumen atas pelayanan yang diberikan. Beberapa perusahaan telah lama menyadari bahwa produk yang hebat tidaklah cukup untuk menarik pelanggan atau yang lebih penting lagi membuat para pelanggan kembali membeli produk itu, dalam memberikan layanan yang bertujuan untuk memberi kepuasan bagi pelanggan di KFC Hasanuddin di Kota Palu, ada beberapa keuntungan yang dapat diambil. Keuntungan pertama yang terbesar yaitu kepercayaan pelanggan, karena pelanggan menilai mutu produk dengan apa yang mereka lihat dan pahami. Keuntungan kedua, bahwa pelanggan mendapat nilai maksimum dari pembeliannya dan memungkinkan pelanggan dengan cepat dan mudah menggunakan seluruh manfaat dari produk yang telah dibelinya. Manfaat dari produk dan layanan yang diberikan kepada pelanggan harus mengarah kepada peningkatan loyalitas pelanggan.

5. Variabel Pelayanan

Berdasarkan Tabel 1, hasil pengujian SPSS diperoleh angka signifikan sebesar 0,008. Angka 0,008 $<0,05$ oleh karena itu, hipotesis diterima. Hal ini berarti terdapat pengaruh variabel Pelayanan terhadap loyalitas konsumen KFC Hasanuddin di Kota Palu. Pelayanan yang diberikan perusahaan merupakan suatu usaha yang dilakukan dalam upaya untuk dapat membuat konsumen menjadi loyal. Nilai pelayanan menjadi rendah bukan karena pelayanan perusahaan KFC Hasanuddin di Kota Palu diturunkan, pelayanan KFC sudah sesuai dengan standar yang diberikan perusahaan pusat, akan tetapi konsumen yang datang ke KFC Hasanuddin di Kota Palu mengganggap biasa dengan pelayanan yang diberikan karena keseringannya konsumen merasakan pelayanan yang diberikan KFC. Konsumen ini sudah tergolong konsumen yang memiliki loyalitas premium, dimana loyalitas premium seperti inilah yang sangat diharapkan oleh perusahaan pada tingkat prefensi yang tinggi, maka konsumen KFC Hasanuddin di Kota Palu akan bangga menggunakan produk tersebut dan dengan senang hati membagi pengetahuan dari pengalaman mereka kepada teman, keluarga, atau konsumen lainya, dan tidak akan berpindah ke perusahaan lainya.

6. Variabel Garansi dan jaminan

Berdasarkan Tabel 1, hasil pengujian SPSS diperoleh angka signifikan sebesar 0,003. Angka 0,003 $<0,05$ oleh karena itu, hipotesis diterima. Hal ini berarti terdapat pengaruh variabel garansi dan jaminan terhadap loyalitas konsumen KFC Hasanuddin di Kota Palu. Berdasarkan hasil pengujian serta analisis yang telah dilakukan pada penelitian ini membuktikan bahwa variabel garansi dan jaminan berpengaruh signifikan terhadap loyalitas konsumen di KFC Hasanuddin di Kota Palu, garansi yang diberikan KFC apabila tidak bisa menyediakan pelayanan yang prima kepada pelanggannya. Adapun indikator-indikator untuk mengukur variabel ini adalah Jaminan pelayanan karyawan yang sopan, kemampuan karyawan untuk berkomunikasi dengan baik, karyawan mempunyai kemampuan yang profesional, karyawan yang memiliki daya tanggap yang cepat terhadap keluhan konsumen, karyawan akan memberikan jaminan pengembalian uang apabila saat 
pembayaran dikasir tidak diberikan struk.

\section{KESIMPULAN DAN SARAN}

\section{Kesimpulan}

1. Nilai (harga dan kualitas) secara parsial berpengaruh signifikan terhadap loyalitas konsumen pada KFC Hasanuddin di Kota Palu.

2. Citra (reputasi dari merek tersebut) secara parsial berpengaruh signifikan terhadap loyalitas konsumen pada KFC Hasanuddin di Kota Palu.

3. Kenyamanan dan kemudahan untuk mendapatkan barang atau jasa secara parsial berpengaruh signifikan terhadap loyalitas konsumen pada KFC Hasanuddin di Kota Palu.

4. Kepuasan yang dirasakan oleh konsumen secara parsial berpengaruh signifikan terhadap loyalitas konsumen pada KFC Hasanuddin di Kota Palu.

5. Pelayanan secara parsial berpengaruh signifikan terhadap loyalitas konsumen pada KFC Hasanuddin di Kota Palu.

6. Garansi dan jaminan secara parsial berpengaruh signifikan terhadap loyalitas konsumen pada KFC Hasanuddin di Kota Palu.

\section{Saran}

1. Kepada perusahaan KFC Hasanuddin di Kota Palu untuk lebih memperhatikan lagi Nilai (harga dan kualitas) terutama buat harga yang terjangkau, agar konsumen bisa menjadi lebih loyal terhadap KFC Hasanuddin di Kota Palu.

2. Kepada perusahaan KFC Hasanuddin di Kota Palu untuk lebih mengembangkan lagi Citra (reputasi dari merek tersebut) agar merek KFC bisa dikenal ke semua orang dan konsumen bisa menjadi loyal terhadap KFC Hasanuddin di Kota Palu.

3. Kepada perusahaan KFC Hasanuddin di Kota Palu untuk lebih mengembangkan lagi Kenyamanan dan kemudahan baik itu barang maupun jasa terutama dalam hal pembayaran di kasir, konsumen masih merasakan antrian yang lama dan panjang. Diharapkan KFC Hasanuddin membuat kasir yang lebih banyak agar pelanggan bisa merasakan kenyamanan dan kemudahan dan akan meningkatkan loyalitas konsumen.

4. Kepada perusahaan KFC Hasanuddin di Kota Palu untuk lebih mengembangkan lagi Kepuasan yang dirasakan oleh konsumen, terutama parkiran yang di sediakan KFC Hasanuddin di Kota Palu harus di perluas agar konsumen bisa merasakan kepuasan karena kepuasan konsumen merupakan suatu hal yang sangat berharga demi mempertahankan loyalitasnya konsumen terhadap KFC Hasanuddin di Kota Palu.

5. Kepada perusahaan KFC Hasanuddin di Kota Palu untuk lebih mengembangkan lagi Pelayanan, terutama untuk pegawai harus lebih bertanggung jawab saat melayani konsumen, karena kualitas pelayanan yang baik bisa menciptakan loyalitas konsumen.

6. Kepada perusahaan KFC Hasanuddin di Kota Palu untuk lebih mengembangkan lagi garansi dan jaminan, terutama untuk pemberian struk ke konsumen saat selesai pembayaran harap di perhatikan, agar konsumen bisa mengetahui uang yang dia keluarkan saat pembayaran, karena semakin baik garansi dan jaminan layanan yang diberikan oleh perusahaan KFC Hasanuddin di Kota Palu maka loyalitas pelanggan akan semakin meningkat.

7. Penelitian-penelitian selanjutnya terhadap KFC sebaiknya memperhatikan variabel-variabel yang di gunakan, baik variabel nya dikurangi atau ditambahkan agar nilai $R$ Square lebih tinggi dari penelitian yang saya lakukan.

\section{REFERENSI}

Abdullah, Thamrin dan Francis Tantri. 2012. Manajemen Pemasaran. Jakarta: Raja Grafindo Persada. 
Alfredo, A.

Alma, Buchari.(2014). Manajemen Pemasaran dan Pemasaran Jasa. Bandung: Alfabeta.

Doyo. (2006) Perilaku Konsumen dan Loyalitas. Yogyakarta: Andi.

Griffin, Jill. (2005). Customer Loyalty, Menumbuhkan dan Mempertahankan Kesetiaan Pelanggan. Jakarta: Erlangga.

Griffin, Jill, (2009). Customer Loyalty: How To Learn It, How To Keep It. Jakarta: Erlangga.

Irawan, Handi. 2009. 10 Prinsip Kepuasan Pelanggan. Jakarta: Elex Media Komputindo.

Kotler. Philip. (2011). Manajemen Pemasaran. Edisi Milenium. Jakarta: PT. Prehallindo.

Kotler, Philip dan Kevin lane keller. (2012). Marketing Management 13.New Jersey: Pearson Prentice Hall, Inc.

Kuncoro, Mudrajad. (2009). Ekonomika Indonesia: Dinamika Lingkungan Bisnis diTengah Krisis Global. Yogyakarta: UPP STIM YKPN.

Payne, Andrian. (2000). Pemasaran Jasa (The Essence of Service Marketing). Terjemahan Fandy Tjiptono. Edisi Pertama. Cetakan Pertama. Yogyakarta: Penerbit Andi.

Sangadji, E.M., dan Sopiah. (2013). Perilaku Konsumen: Pendekatan Praktis Disertai:Himpunan Jurnal Penelitian. Yogyakarta: Penerbit Andi.

Sugiyono. (2013). Metode Penelitian Kuantitatif dan R\&D. Bandung: Alfhabeta.

Stöcklin dan Opwis. (2008), “Whence Consumer Loyalty”, Journal of Marketing. Volume 63 Special Issue, pp. 33-44.

Tjiptono, Fandy. (2008). Strategi Pemasaran. Edisi 3. Yogyakarta: Andi Offset

Tjiptono, Fandy. (2014). Pemasaran Jasa. Yogyakarta: Andi. 